\title{
The Indian film industry in a changing international market
}

\author{
Sayantan Ghosh Dastidar ${ }^{1} \cdot$ Caroline Elliott $^{2}[$
}

Received: 28 February 2018 / Accepted: 16 April 2019

(c) The Author(s) 2019

\begin{abstract}
India has a longstanding reputation for its acclaimed film industry and continues to be by far the world's largest producer of films. Nevertheless, domestic demand for films appears to be waning as in a number of developed countries with mature film industries. Hence, the econometric analysis in this paper is particularly timely as with demand for films in Indian cinemas falling it is important to identify those factors that make films appealing for Indian audiences. An original dataset is utilised that includes data on all Bollywood films released in India between 2011 and 2015. Account is taken of the potential endogeneity between variables through the use of the generalised method of moments approach. Results are used to demonstrate how the Indian film market can continue to have a significant positive impact on the Indian economy. The discussion highlights appropriate film production company strategies and government policy responses that should be considered to ensure the continued success of the Indian film industry both domestically and in an increasingly competitive international market.
\end{abstract}

Keywords India $\cdot$ Institutions $\cdot$ Competition $\cdot$ Film performance $\cdot$ Quality signals

JEL Classification C21 $\cdot \mathrm{D} 12 \cdot \mathrm{L} 10 \cdot \mathrm{L} 82 \cdot \mathrm{Z} 11$

\section{Introduction}

India has a longstanding reputation for its acclaimed film industry, with the term Bollywood synonymous with vividly coloured films featuring complex dance routines, singing and spectacular large cast scenes. India continues to be by far the

Caroline Elliott

c.elliott4@aston.ac.uk

Sayantan Ghosh Dastidar

s.dastidar@derby.ac.uk

1 College of Business, Law and Social Science, University of Derby, Kedleston Road, Derby DE22 1GB, UK

2 Aston Business School, Aston University, Birmingham B4 7ET, UK 
Table 1 Film industry statistics

\begin{tabular}{|c|c|c|c|c|c|c|c|c|c|}
\hline Country & 2005 & 2006 & 2007 & 2008 & 2009 & 2010 & 2011 & 2012 & 2013 \\
\hline \multicolumn{10}{|c|}{ Number of feature films produced } \\
\hline India & 1041 & 1091 & 1146 & 1325 & 1288 & 1274 & 1255 & 1602 & 1724 \\
\hline China & 260 & 330 & 411 & 422 & 475 & 542 & 584 & 745 & 638 \\
\hline USA & 699 & 673 & 789 & 773 & 751 & 792 & 819 & 738 & 738 \\
\hline UK & 106 & 107 & 124 & 279 & 313 & 346 & 299 & 326 & 241 \\
\hline \multicolumn{10}{|c|}{ Total number of admissions (millions) } \\
\hline India & 3770 & 3997 & 3290 & 3251 & 2777 & 2706 & 2640 & 2641 & 1978 \\
\hline China & 157 & 176 & 196 & 210 & 264 & 290 & 370 & 470 & 612 \\
\hline USA & 1403 & 1449 & 1399 & 1341 & 1415 & 1342 & 1284 & 1358 & 1343 \\
\hline UK & 165 & 157 & 162 & 164 & 174 & 169 & 172 & 173 & 166 \\
\hline \multicolumn{10}{|c|}{ Attendance frequency per capita } \\
\hline India & 3.79 & 3.95 & 3.20 & 3.12 & 2.62 & 2.52 & 2.38 & 2.34 & 1.73 \\
\hline China & 0.13 & 0.14 & 0.16 & 0.17 & 0.21 & 0.23 & 0.29 & 0.37 & 0.48 \\
\hline USA & 5.24 & 5.37 & 5.14 & 4.88 & 5.09 & 4.78 & 4.54 & 4.76 & 4.67 \\
\hline UK & 3.04 & 2.88 & 2.97 & 3.00 & 3.15 & 3.06 & 3.09 & 3.05 & 2.91 \\
\hline \multicolumn{10}{|c|}{ Average ticket price (US\$) } \\
\hline India & N/A & 0.34 & 0.53 & 0.57 & 0.51 & 0.50 & 0.56 & 0.60 & 0.81 \\
\hline China & 1.55 & 1.86 & 2.22 & 2.89 & 3.45 & 5.18 & 5.49 & 5.75 & 5.74 \\
\hline USA & 8.50 & 8.96 & 11.56 & 10.49 & 10.22 & 9.35 & 10.59 & 10.83 & 10.90 \\
\hline UK & 6.41 & 6.55 & 6.88 & 7.18 & 7.50 & 7.89 & 7.93 & 7.96 & 8.13 \\
\hline
\end{tabular}

Source: UNESCO Institute for Statistics www.uis.unesco.org

world's largest producer of films, producing 1724 films in 2013 compared to 738 films produced in the USA, and 638 films produced in China. ${ }^{1}$ Nevertheless, domestic demand for films appears to be waning as in a number of developed countries including the USA and UK. For comparison purposes, film industry data for China, the USA and the UK as well as India are provided in Table 1.

It is immediately clear that while India produces by far the greatest number of films, with the number of films produced continuing to rise, the number of consumers paying to see films at cinemas in India has declined dramatically in recent years, despite significant growth in GDP since 2000 and international investment in the Indian film industry, Fetscherin (2010). However, falling popularity of going to the cinema is not exclusive to India, with falls in cinema ticket sales also seen in the USA and UK. Each of these film markets can be considered mature markets, with long established, successful film production industries, and cinema visits a longestablished social activity. Indeed, the first full-length Indian film, Raja Harischan$d r a$, was produced in 1913, and by the 1920s, large-scale Indian film studio companies existed, and Mumbai had established itself as an early hub for film making (to

\footnotetext{
1 UNESCO Institute for Statistics, www.uis.unesco.org.
} 
become known as Bollywood). See Jones et al. (2008) for a history of the Indian film industry.

The importance of the Indian film industry to the Indian economy cannot be overstated: in 2012, Indian cinema box office revenues were $\$ 1.6$ billion (McCarthy, 2014), in a services sector which accounts for more than $50 \%$ of the Indian economy. ${ }^{2}$ Fetscherin (2010) suggests that the film industry accounts for approximately $20 \%$ of all revenues in the Indian media and entertainment industries. Further, despite the high profile of 'Bollywood' which is based in Mumbai, film production also has positive spillover benefits to other local economies, particularly Chennai where film production has long been established, with films made in four key southern Indian languages. There are also notable film production activities in Hyderabad, Karnataka, Kolkata and Kerala that benefit the local economies. Local economy benefits are not restricted to the direct benefits and multiplier effects associated with film production and therefore employment in specific local economies. Bollywood, in particular, also has tourism benefits with Bollywood locations boosting tourist visitor numbers, i.e. an indirect channel through which the Indian film industry contributes to gross domestic product (GDP).

Yet, the Indian film industry currently faces a number of challenges. First, a major challenge remains film piracy which limits the revenues that can be reinvested by producers, distributors and exhibitors. A complicated system of regulations with responsibility shared by a number of national and state level government departments only contributes to the often ineffective nature of policies and laws that should guard against piracy, Jones et al. (2008). The problem of piracy results in lower revenues across the film industry, and the negative effect on investment in the industry is compounded by the high entertainment tax rates imposed in India.

Second, relative to many countries, domestic cinema ticket prices remain low, Jones et al. (2008) and see Table 1. This again results in smaller box office revenues to be shared between film exhibitors, distributors and producers, reducing opportunities for reinvestment across the Indian film industry. This is particularly important at the moment as international film producers are increasingly investing in expensive technology associated with 'enhanced format' films, such as 3D and IMAX. Elliott et al. (2018) have found these films particularly popular with Chinese audiences, but these films require very large production budgets, as well as investment in cinemas by film exhibitors. Nevertheless, despite the costs of producing enhanced format films, they offer the advantage that the piracy of these films is less attractive as the special effects will be much less impressive to viewers when watching pirated films either on television screens or computer monitors. A further issue relating to low ticket prices is that regardless of this advantage, consumers are still purchasing fewer cinema tickets.

Meanwhile, despite difficulties until the early 1990s, the Chinese film market now continues to grow rapidly, both in terms of films produced and audiences' desire to view films at cinemas. Despite initially slow growth of the film industry in China prior to the 1990s, its film box office revenues were expected to exceed $\$ 10$ billion

\footnotetext{
${ }^{2}$ World Bank. World Development Indicators.
} 
in 2016, coming close to overtaking the USA which enjoyed box office revenues of $\$ 11$ billion in 2015, Shoard (2016). It is within this context that the performance of the Indian film industry has to be considered. The Indian and Chinese film industries share some similarities. Both countries have adopted economic liberalisation policies since the later years of the twentieth century, and as a result in both countries, the film industry has attracted greater foreign investment. Meanwhile, liberalisation has led to greater competition for domestic films from large budget, internationally produced films, often originating in Hollywood, with both Indian and Chinese audiences keen to watch these films.

This paper seeks to identify the factors that contribute to films' success in Indian cinemas using an econometric analysis such that film production companies are in a better position to identify strategies to ensure their future success. These strategies relate to film characteristics as well as marketing strategy. Given the importance of the film industry to the Indian economy and the difficulties currently faced by the industry, our analysis is particularly important and timely. We believe this to be the first paper econometrically to estimate the determinants of domestic box office success for the Indian film industry. To do this, an original dataset has been collated and utilised, considering all Bollywood films released in Indian cinemas over the period 2011 to 2015. For each film, released data are collected on the size of production budget; Indian cinema box office revenues; film genre; the use of Bollywood star actors and directors; and the distributor of the film in India. Alternative measures of critical acclaim for each film are also collected. As well as identifying those factors associated with films' Indian box office success, the results of the statistical analysis are used to develop government policy recommendations.

A literature review covering economic analyses of the film industry, both in India and more broadly, is provided in Sect. 2. The data and econometric methodology are described in Sect. 3. Results are reported in Sect. 4, with discussion of these results, policy implications and conclusions provided in Sect. 5.

\section{Literature review}

Despite the large and burgeoning film industry literature, spanning the Economics, Marketing and Management disciplines, there are very few analyses of the Indian film industry. The only econometric analysis of factors impacting on Indian film success is that of Fetscherin (2010), who considers the variables that affect the opening week and total cinema box office returns of Indian films exhibited in the UK and USA. Fetscherin (2010) concludes that neither star power nor the previous directing experience of the director impacted on opening week or total box office revenues, and that consumer online reviews, posted on the www.imdb.com website, also had no significant impact on either revenue variable. Our statistical analysis differs as we are interested in the factors determining the success of Indian films in the domestic, Indian market. Arguably, our analysis is also strengthened as we were able to obtain data on film production budgets and film critic review scores and could identify if a film was a sequel. Other analyses of the impact of the Indian film industry include Jones et al. (2008) and Balasubramanyam (2009), but a lack of Indian film industry 
data has resulted in a paucity of Indian analyses despite the high profile of Bollywood. Our analysis contributes directly to this limited literature.

A film represents an experience good, for which full details of the properties and quality of the good cannot be determined, prior to purchase and consumption. Consequently, it is important for consumers to receive quality signals in advance of cinema ticket (or DVD) purchase decisions, to help ensure that consumers select films that best match their preferences. Beyond the Indian market, there is a large literature that considers the factors that determine films' box office success, and much of the literature highlights factors that can be considered quality signals. See Mckenzie (2012) for a recent literature survey.

A number of potential quality signals under the control of film production companies have been considered, with research estimating their impact on film box office revenues. A consensus has emerged in the literature that there is a positive, significant relationship between a film's budget and box office revenues with consumers perceiving higher film budgets as a signal of film quality, Elliott et al. (2018). ${ }^{3}$ Related to film budget, one of the most expensive costs of producing a film may be the costs of employing high profile star actors and actresses. The use of stars is a very visible signal that production companies are willing to invest large amounts of money in a film, and also signals the actors' belief in the quality of a film. A number of researchers have considered the impact of employing stars in films, including US analyses of Prag and Casavant (1994), Ravid 1999), Elberse (2007), Brewer et al. (2009), Akdeniz and Talay (2013), the Italian analysis of Bagella and Becchetti (1999), as well as Fetscherin's (2010) Indian analysis. However, results remain mixed, with some but not all studies concluding that the use of stars positively impacts on film box office revenues. Similarly, the use of a high profile film director as a signal quality that may impact positively on box office revenues has been considered by Bagella and Becchetti (1999) as well as Fetscherin (2010).

If a film is successful in terms of box office revenues, this may then encourage film production companies to invest in a sequel, as considered by, Basuroy et al. (2003), Moon et al. (2010), Akdeniz and Talay (2013). Similarly, cinemagoers may be eager to pay to view a sequel if they have enjoyed an earlier film in a film franchise. Elliott et al. (2018) conclude that Chinese audiences are positively attracted to sequel films. The final quality signal under the control of film production and distribution companies is the date of release of a film, with firms keen for films that they think will particularly appeal to audiences to be screened around major holiday periods. This has previously been explored in a US context by Litman (1983), Sochay (1994), Einav (2007) and Brewer et al. (2009) and is considered in the Indian context in the analysis below.

A second set of potential quality signals that may influence consumers' film ticket purchase decisions is not under the control of film production companies, namely expert critics' review scores and online review scores given by members

\footnotetext{
${ }^{3}$ Note that unlike in many industries where films try not to reveal their costs of production for fear of providing information to competitors, film budgets are typically published, for example with data readily available on websites such as www.imdb.com.
} 
Table 2 Descriptive statistics

\begin{tabular}{lcccc}
\hline Variable & Mean & $\begin{array}{l}\text { Standard devia- } \\
\text { tion }\end{array}$ & Maximum & Minimum \\
\hline TOTAL REVENUE & 27.80 & 36.48 & 196.15 & 0.02 \\
OPENING WEEK REVENUE & 19.99 & 24.79 & 130.40 & 0.001 \\
BUDGET & 19.76 & 22.20 & 151.21 & 0.06 \\
ONLINE REVIEW & 5.69 & 1.49 & 8.50 & 1.90 \\
\hline
\end{tabular}

TOTAL REVENUE, OPENING WEEK REVENUE and BUDGET are reported in 10 million (crore) Indian rupees, 2010 constant prices

of the general public. The impact of critics' review scores on box office revenues has been explored by Eliashberg and Shugan (1997), Basuroy et al. (2003), Reinstein and Snyder (2005) in the US context, and by Elliott and Simmons (2008) using UK data. Nevertheless, Moon et al. (2010) suggest that consumers may take more note of consumer reviews than those of expert critics. The increasing availability of online review scores posted by non-expert reviewers has led to Elliott et al. (2018) exploring the impact of these reviews on Chinese box office revenues, concluding that these reviews are positively and significantly related to box office revenues.

All of the quality signals highlighted above, including both those under the control of film production companies, and those associated with expert and non-expert critics are considered in the statistical analysis below.

A crucial issue addressed in the literature is how to take account of the potentially highly skewed distribution of film revenues which may also be characterised by unbounded variance, as identified by Collins et al. (2002); De Vany and Lee (2001); De Vany and Walls (1996, 1999, 2002). These characteristics result in film revenue variables violating the classical assumptions required for ordinary least squares (OLS) of variables having well-defined mean and constant and finite variance. De Vany and Walls $(1999,2002)$ have suggested using the Pareto distribution to deal with the excessive kurtosis; Collins et al. (2002) used an ordered Probit model with threshold revenue values imposed, while Walls (2005) recommends using a t-skew distribution. These issues will be addressed in Sect. 3 .

\section{Data and methodology}

\subsection{Data}

The dataset comprises all Bollywood films screened in Indian cinemas over five years, 2011-2015 for which data on all required variables were available. This gives rise to a dataset of 245 films as data were missing on key variables for a number of films released in India during this period. Nevertheless, we believe this to be the largest dataset collated to date on the Indian film industry. Variable definitions and data sources are detailed in Appendix 1, while descriptive statistics for the continuous variables are reported in Table 2. 
Both total Indian film box office revenues and opening week box office revenues are used as dependent variables (REVENUE). While much of the literature focuses on factors that determine total box office revenues, we also consider opening week revenues as these are particularly important in the Indian film market context given the rapidity with which films are pirated, with film revenues often falling rapidly within the first two weeks after they are released. Both variables are reported in 10 million Indian Rupees INR (crore) and converted into real values taking 2010 as the base year and using World Bank Consumer Prices Index (CPI) data from 2011 to 2015 to deflate the budget and box office revenue values during 2011-2015. Hence, the budget and revenue variables used are in 2010 constant prices. As is standard in the film industry literature, the revenue and budget variables are logged in the statistical analysis. In Sect. 2, we highlighted that previously researchers have identified that box office revenues may not be normally distributed. We tested for skewness and kurtosis of our revenue variables. As anticipated, non-logged opening week and total revenues do suffer from kurtosis with values of 4.63 and 5.30, respectively. However, the skewness values are less concerning at 2.08 and 2.17 for opening week and total revenues, respectively. Reassuringly, the values for the logged variables indicate less of a problem with skewness and kurtosis, as the values for skewness are -1.59 and -1.08 , and with kurtosis values of 2.61 and 1.23 , again for opening week and total revenues, respectively.

As well as BUDGET, a number of further potential quality signals are used as explanatory variables. A dummy variable STARPOWER was created, indicating the reputation of the leading actor/actress. There are many rankings of Bollywood actors and actresses but the TIMES Celebex ranking is often considered the most well respected. The data of 2011 are not available as the ranking was only launched in 2012, Guptal (2015). Hence, we consider a film to have an actor/actress with star power if they have been in the TIMES Celebex ranking at any time during 2012-2015. There are approximately five actors and five actresses in the ranking in any one year, with persistence of actors and actresses in the top five ranking for at least one year and sometimes throughout the period 2012-2015. See Appendix 2 for a list of actors and actresses who are considered to have star power in our analysis. An alternative star power explanatory variable was also created, and rather than a dummy variable, this was a count variable of the number of films that the leading actor/actress had been in during their career, the data taken from www.imdb.com. This is in line with Chang and Ki (2005) and Fetscherin (2010) who similarly count the number of films an actor or actress has appeared in as a measure of star power. However, the coefficient on this variable was insignificantly different from zero; this also the case when the variable plus the squared variable were used reflecting a possible nonlinear relationship between star power and box office revenues. Hence, the statistical analysis continued using the dummy STARPOWER variable. As a further robustness check, the regression analysis was repeated using an interaction variable STARPOWER * (logged) BUDGET, but again, the coefficient on this explanatory variable was insignificantly different from zero so results with this interaction variable were excluded from the model. Again following Chang and Ki (2005) and Fetscherin (2010), a DIRECTORPOWER variable was created by counting the number of 
films a director had previously directed to reflect the star power and experience of a director.

Initially, regressions were run including a quality signal variable of Times of India critics' film review scores, CRITIC. The reviews in this newspaper were selected as the Times of India is the largest selling English daily newspaper sold in India. However, this quality signal was not found to influence cinemagoers significantly and it was dropped from the analysis. Instead, mean online review scores for films posted on the internationally well-known website www.imdb. com were collected and used as an alternative quality signal, ONLINEREVIEW. Audiences will often submit online review scores very soon after films' release that further potential audiences can access easily prior to deciding which films to watch at the cinema. Moon et al. (2010) conclude that for potential audiences, online reviews are a better quality signal than expert review scores.

A dummy variable, DISTRIBUTOR, was included to indicate a film distributed in India by one of the ten largest film distribution companies. However, given that the coefficient on this variable was consistently found to be insignificantly different from zero, alternative distributor dummy variables were also created. Given the traditional importance of family firms in the Indian economy, DISTRIBUTORFAM indicates that the distribution company is family owned, while DISTRIBUTORFAM10 indicates that a film was distributed by one of the ten largest distribution companies that are family owned. Only the coefficient on DISTRIBUTORFAM10 was ever found to be significantly different from zero so this is the variable used in the analysis below.

A SEASON dummy variable, taking the value unity when a film was released in India during key Muslim, Hindu and Christian festivals as well as around Independence Day, Republic Day and New Year, was also included to aid comparability with studies published that consider the impact on revenues of films released around major holiday periods. See Appendix 3 for details. Yet, again the coefficient on this explanatory variable was found to be insignificantly different from zero. Hence, alternative forms of this variable were considered. Successively, less important festivals were assigned a zero value, and the regressions rerun to test if the coefficient on the SEASON dummy variable became significantly different from zero. However, even when only the three largest festivals were assigned a value of unity, namely Christmas, Diwali and Eid, the coefficient on the SEASON dummy variable remains insignificantly different from zero. It is this final iteration of the SEASON dummy variable which is used in the results below. Both the DISTRIBUTOR and SEASON dummy variables can be considered potential quality signals as films expected to do well at the box office are likely to attract major distributors, with production and distribution companies keen to release films that they anticipate will do well around holiday periods.

Alternatively, potential film audiences may only have limited leisure time and have to select between alternative leisure activities. Izquierdo Sanchez et al. (2016) highlight that when key football tournaments take place, potential European cinema audiences may choose instead to watch football matches. Hence, to test whether potential Indian film audiences similarly select between cinema visits and the watching of major cricket matches, a dummy variable CRICKET is 
Table 3 Revenue regression results

\begin{tabular}{|c|c|c|}
\hline \multirow[t]{2}{*}{ Explanatory variable } & \multicolumn{2}{|c|}{ Dependent variable } \\
\hline & Total revenue & Opening week revenue \\
\hline$L O G B U D G E T$ & $\begin{array}{l}1.3141 * * * \\
(0.1036)\end{array}$ & $\begin{array}{l}1.2623^{* * * *} \\
(0.1009)\end{array}$ \\
\hline ONLINEREVIEW & $\begin{array}{l}0.1733 * * * \\
(0.0481)\end{array}$ & $\begin{array}{l}0.1135^{* *} \\
(0.0453)\end{array}$ \\
\hline DISTRIBUTORFAMIO & $\begin{array}{l}0.2437 \\
(0.1528)\end{array}$ & $\begin{array}{l}0.2461^{*} \\
(0.1490)\end{array}$ \\
\hline SEASON & $\begin{array}{l}-0.3374 \\
(0.3219)\end{array}$ & $\begin{array}{l}-0.3462 \\
(0.3175)\end{array}$ \\
\hline CRICKET & $\begin{array}{l}0.1696 \\
(0.2368)\end{array}$ & $\begin{array}{l}0.1444 \\
(0.2213)\end{array}$ \\
\hline ROMANCE & $\begin{array}{l}-0.4074 \\
(0.2605)\end{array}$ & $\begin{array}{l}-0.4187^{*} \\
(0.2456)\end{array}$ \\
\hline$A C T I O N$ & $\begin{array}{l}-0.3980^{*} \\
(0.2170)\end{array}$ & $\begin{array}{l}-0.3260 \\
(0.2096)\end{array}$ \\
\hline DRAMA & $\begin{array}{l}-0.6703^{*} \\
(0.2590)\end{array}$ & $\begin{array}{l}-0.6312 * * \\
(0.2493)\end{array}$ \\
\hline SEQUEL & $\begin{array}{l}0.4120^{*} \\
(0.2352)\end{array}$ & $\begin{array}{l}0.3833^{*} \\
(0.2229)\end{array}$ \\
\hline CONSTANT & $\begin{array}{l}-22.6545^{* * * *} \\
(1.9466)\end{array}$ & $\begin{array}{l}-21.6200 * * * \\
(1.8967)\end{array}$ \\
\hline Observations & 245 & 245 \\
\hline GMM C statistic & $30.084 * * *$ & $27.7628 * * *$ \\
\hline Hansen $\mathbf{J}$ statistic & 0.2331 & 0.3529 \\
\hline
\end{tabular}

Multicollinearity is confirmed not to be an issue as in the OLS regressions we obtained mean VIF scores of 1.3 and 1.32 with total revenue and opening week revenue, respectively, as dependent variables (both VIF scores considerably lower than 10)

Robust standard errors in brackets; $* p<0.10 ; \quad * * p<0.05$; $* * * p<0.01$

included that takes the value unity for films released during the Indian Premier League (IPL) season. ${ }^{4}$

A set of genre dummy variables was included as these are commonly included in statistical analyses in the literature. For example, Elliott and Simmons (2008) conclude that, in the UK, films targeted at children do well, while Ravid and Basuroy (2004) consider US R-rated films, which are targeted at adult audiences. In our analysis, we categorised the films into the following genres COMEDY, DRAMA, ROMANCE and ACTION/THRILLER where COMEDY was treated as the control category of genre. Finally, a dummy SEQUEL variable was included, taking the value unity if a film was a sequel in a film franchise. Audiences may take a film's sequel status as a signal of quality if they have enjoyed another film in a film

\footnotetext{
${ }^{4}$ The Indian Premier League (IPL) is the most popular cricketing event in India and is also the most watched T20 cricket league internationally, Barrett (2016).
} 
franchise, while film production companies may be keen to invest in a sequel if a previous film in a franchise has had box office success.

Inspection of the correlation matrices indicated that multicollinearity is not expected to be a particular concern in the statistical analysis. ${ }^{5}$ The lack of multicollinearity is confirmed in the results, Table 3.

\subsection{Methodology}

The model first estimated was an ad hoc model with explanatory variables chosen following a thorough review of the film industry literature. Hence, we started by estimating the following equation:

$$
\begin{aligned}
& \text { REVENUE }_{\mathrm{i}}=\beta_{0}+\beta_{1} \text { BUDGET }_{\mathrm{i}}+\beta_{2} \text { STARPOWER }_{\mathrm{i}}+\beta_{3} \text { DIRECTORPOWER }_{\mathrm{i}} \\
& +\beta_{4} \text { DISTRIBUTORFAM10 } 0_{\mathrm{i}}+\beta_{5} \text { SEASON }_{\mathrm{i}}+\beta_{6} \text { CRICKET } \\
& +\beta_{7} D_{R A M A_{\mathrm{i}}}+\beta_{8} \text { ROMANCE }_{\mathrm{i}}+\beta_{9} \text { ACTION }_{\mathrm{i}} \\
& +\beta_{10} S E Q U E L_{\mathrm{i}}+\beta_{11} \text { CRITIC }_{\mathrm{i}}+\mathrm{e}_{\mathrm{i}}
\end{aligned}
$$

for movie i, e denotes the error term.

Initially, the model was estimated using OLS, with robust standard errors to correct for potential heterscedasticity in the residuals. However, if there is endogeneity or reverse causality in the model, then the OLS results will be biased and unfit for drawing inferences. Potentially, there may be reverse causality from REVENUE towards $B U D G E T$ as production companies decide film budget levels partly on the expectation of film revenues that are likely to accrue. Further, as highlighted in Sect. 2, it is generally accepted in the film industry literature that film budget may be a quality signal to potential audiences, with consumers believing that higher budget films are likely to be of higher quality. To test this hypothesis, we estimated the following model (Eq. 2) and employed the GMM C test to assess whether BUDGET is endogenous in our model.

$$
\begin{aligned}
& \text { BUDGET }_{\mathrm{i}}=\beta_{0}+\beta_{1} \text { REVENUE }_{i}+\beta_{2} \text { STARPOWER }_{i}+\beta_{3} \text { DIRECTORPOWER }_{i} \\
& +\beta_{4} \text { DISTRIBUTORFAM } 10_{i}+\beta_{5} \text { SEASON }_{\mathrm{i}} \\
& +\beta_{6} \text { CRICKET }+\beta_{7} \text { DRAMA }_{i}+\beta_{8} \text { ROMANCE }_{i} \\
& +\beta_{9} \text { ACTION }_{i}+\beta_{10} S E Q U E L_{i}+\beta_{11} \mathrm{z}_{\mathrm{i}}+\mathrm{u}_{\mathrm{i}}
\end{aligned}
$$

where $\mathrm{z}$ denotes the residuals obtained from the estimation of Eq. 1 and $\mathrm{u}$ is the error term.

The quality signal CRITIC was dropped from the model because it is determined post-release of the movie and therefore cannot have any influence on the budget of a movie. We use STARPOWER and DIRECTORPOWER as the instruments of $B U D G E T$ as the estimation results for Eq. 1 indicated that neither of these

\footnotetext{
$\overline{5}$ Correlation results withheld for the sake of brevity but available on request.
} 
variables affect REVENUE directly. Both variables may impact on film budget as it may be more expensive to employ film stars and/or a director with greater previous experience.

The results indicated that $B U D G E T$ is indeed endogenous, and so, to control for this issue, we continued our estimation of the model in Eq. 1 by employing the instrumental variable general method of moments (GMM) approach. ${ }^{6}$ Both the OLS and GMM estimation results indicated that expert critic ratings have no effect on the box office revenues of films. Hence, in the results reported in Sect. 4, the CRITIC variable is replaced with the ONLINEREVIEW variable as a quality signal outside the control of film production companies. Finally, note that the methods proposed by Collin et al. (2002); De Vany and Walls (1999, 2002) and Walls (2005) for dealing with non-normally distributed film revenues have the cost attached that because of computational complexity, it is only possible to estimate a reduced form model rather than a structural model. As we are able to confirm that BUDGET is in fact endogenously determined, and because the skewness and kurtosis values for our logged REVENUE variables do not give cause for major concern, we are reassured that it is appropriate to use the GMM approach, the results of which are reported in Sect. 4.

\section{Econometric results}

Regression results for the key film box office revenue dependent variables are reported in Table 3, controlling for endogeneity as outlined in the section above. The first thing to note is the robustness of the results, regardless of whether total or opening week box office revenues are selected as the dependent variable. This result is in line with expectations given the short period of time that films remain popular on Indian cinema screens, and the rapidity with which films are pirated. The Hansen $\mathbf{J}$ statistic indicates that the instruments are valid as are the over-identification restrictions.

The magnitude of a film's budget is found to be key to a film's success: budget has a positive, significant effect on both opening week box office revenues and total revenues. A film's budget is one potential quality signal to consumers of the film's quality. Unlike for many goods, film companies are often happy to reveal large budgets attached to film production. A large budget indicates a production company's faith in the quality of film being produced, and film budget data are routinely reported on websites such as www.imdb.com. Indian film budgets typically remain low compared to those of Hollywood films (Balasubramanyam 2009), but as in previous USA and UK studies, a higher budget is associated with film box office success.

The other signal of quality that is found to be a crucial influencer is the mean of online review scores posted by the general public on www.imdb.com. Again,

\footnotetext{
${ }^{6}$ OLS results are provided in Appendix 4 for thoroughness and to illustrate the robustness of our GMM results.
} 
the coefficient on this variable is always positive and significant, regardless of whether we consider its impact on opening week revenues or total revenues. This impact of online reviews is in line with that found in Elliott et al. (2018) in the Chinese film market context and highlights the importance for production and distribution companies of establishing and maintaining effective communication with potential audiences.

No consensus has been reached in the literature to date on whether films enjoy greater revenues if they are released around major holidays. For example, Litman (1983) suggests that Christmas is the optimum time to release a film in the USA, while Sochay (1994) concludes that the summer holiday period is preferred, with Brewer et al. (2009) supporting this result but also indicating that in the US films perform better if they are released around Thanksgiving. Our results indicate that release date has no significant impact on a film's box office revenues in the Indian market despite testing various formulations of the SEASON dummy variable. This may reflect the diversity of holiday dates in the Indian calendar as highlighted in Appendix 3. Similarly, in the econometric analysis, we test whether films perform significantly worse if released in the IPL season but find no significant evidence of this. This result indicates that Indian audiences do not substitute between viewing films at the cinema and watching major cricket matches.

If a film is a sequel, our results suggest that this may have a limited, positive impact on a film's success. Consequently, a film's sequel status may be a weak indicator of film quality. Meanwhile, while films distributed by an Indian top ten distribution company that is family owned may not perform significantly better in terms of total box office revenues, they enjoy greater box office success in the opening week of general Indian release, at least at a ten per cent significant level. This suggests that until film quality information is spread through word-ofmouth, for example, through IMDB online reviews, the distributor of films can have some impact on opening week revenues.

Finally, the coefficients on the genre dummy variables indicate that films that can be categorised as romantic, action/thriller or drama all perform significantly worse in terms of box office revenues than the excluded film category - comedies.

Note that in initial regressions, the use of star actors and actresses and major distributors were not found to impact significantly on box office revenues, even though both may be considered as potential signals of a film's quality. These variables have been found to have a positive, significant effect on revenues in a number of country contexts previously, see for example Elliott et al. (2018). Nevertheless, the result in the current analysis is in line with that of Fetscherin (2010) who also considers the Indian market. This result is encouraging as it indicates that two potential barriers to entry, namely the use of costly stars and distributors, are not important in the Indian film industry context.

The analysis above contributes directly to our understanding of the question posed in this research paper, namely what factors contribute to a film's box office success in the Indian market. Results suggest that two factors are key and are signals of film quality, namely film budget and online review scores. The first, but not the second, is under the control of film production companies. 


\section{Discussion and conclusions}

Higher film budgets and better online reviews result in higher Indian box office revenues for Bollywood films, a result in line with conclusions previously drawn for the Chinese film market, Elliott et al. (2018). Comparisons between the Indian and Chinese film markets are arguably appropriate as there are similarities between these two major Asian economies that similarly have liberalised in recent years, both subsequently enjoying substantial economic growth. However, while economic growth is associated with greater spending power at least for many consumers, demand for Indian films at Indian cinemas has stagnated, while in China, it has flourished. Other potential quality signals found to impact on Chinese film revenues, namely the production of sequels, the use of stars and major distribution companies, do not significantly affect Indian film revenues. These results may be indicative of a potentially competitive Indian film industry. While admittedly large film budget is important for box office success, production firms including new entrants do not need to rely on the use of stars or major distribution companies. This is reassuring as it is potentially more difficult for new production company market entrants to attract stars and major distribution companies to film projects. Note that Balasubramanyam (2009) also highlights the competitive nature of the Indian film industry, but rather indicates the lack of horizontal and vertical integration, the importance of family firms and the industry's spread across the country. Yet, the competitive nature of the Indian film industry does not explain its recent difficulties, namely falling cinema attendance. As Elliott et al. (2018) note, the Chinese film industry is also increasingly becoming competitive.

Our results indicate that production firms should work to obtain financial backing for film projects, be that domestic funding or international funding, including from major Hollywood firms. Yet, while a competitive market is typically seen as advantageous as firms compete to satisfy consumer demands, can learn from each other, and have an incentive to produce efficiently, Indian film production companies should also consider whether too many films are currently being produced. This is particularly pertinent as consumer demand for watching films at the cinema is declining. Arguably fewer, larger budget, films should be produced with production companies focusing on producing higher quality films more likely to attract positive online reviews. Any marketing activities that may encourage positive online reviews should also be considered, and firms need to be aware that comedy films appear to be most popular with Indian audiences. Meanwhile, the timing of the release of a film in India appears irrelevant to its box office success. This may be explained by the diversity of audiences who speak different languages, and who celebrate festivals associated with different religions.

Producing films that can be exported successfully to increasingly sophisticated and better off diaspora is likely to remain a sensible strategy for film production companies, particularly as the Indian diaspora are believed to exceed 20 million, Jones et al. (2008). This strategy for Indian films has already been adopted, with the USA and UK being profitable export markets for Indian films, Eliashberg 
et al. (2006); Fetscherin (2010). However, exports of Indian films only make up approximately $10 \%$ of box office revenues and this figure has fallen slightly in recent years from $10.6 \%$ in 2010 to $9.2 \%$ in $2014 .{ }^{7}$ Examples of particularly successful Bollywood films overseas include Monsoon Wedding (2001) and Slumdog Millionaire (2008). These are both relatively large budget films so reinforcing the importance of greater film budgets. The Industrial Development Bank of India (IDBI) set up India's first major film fund in 2002, Jones et al. (2008). This initiative is important, but further large-scale investment is required, and the likelihood is that this will partly be funded by overseas, probably Hollywood investment, as well as domestic funds.

Nevertheless, attempts by Hollywood to produce films for domestic audiences have not always been successful, with locally produced films performing better at the box office. Even using Indian casts, crew and directors, it appears that USbacked films can struggle with possible 'cultural discount'. The cultural discount hypothesis has already received support in other East Asian film markets, as discussed by, for example, Lee (2006, 2009), Fu and Lee (2008), Moon et al. (2015). Our results above highlight the importance of film budgets, with higher budget films performing significantly better at the Indian box office. Then, the challenge will be to produce films that appeal to domestic audiences, and to do this, the notion of cultural discount will have to be at the forefront of producers' concerns. The issue of cultural distance is complicated in the case of India by the number of languages in which films are produced, for example with films regularly made in the Bengali; Bhojpuri; Hindi; Kannada; Tamil; and Telugu languages, but the lack of a common language immediately limits the appeal of films to some Indian audiences, creating cultural distance even within country boundaries. Nevertheless, revenues are made from dubbing films into alternative local languages, or by remaking films with regional stars (Balasubramanyam 2009).

The challenge of producing big budget films that appeal to audiences is further complicated as evidence suggests that Indian film audiences are becoming increasingly sophisticated in their tastes, for example rejecting more formulaic plots. Meanwhile, middle-class film viewers are increasingly choosing to watch films in the comfort of their homes via cable television subscriptions or the Internet. ${ }^{8}$

The statistical analysis above has a number of limitations, all reflecting data availability problems. Data are restricted to Bollywood films, although results are expected to be comparable for the film industry more broadly across India. This is an area for future research. Data could not be obtained on film advertising expenditures, the number of screens on which films are exhibited in their opening week, major Indian film award nominations both in India and internationally, and any enhanced format features of films released in India. Nevertheless, results for the Chinese film market reported by Elliott et al. (2018) indicate that enhanced format films are likely to become increasingly important in attempts to attract cinema audiences as well as

\footnotetext{
7 https://assets.kpmg.com/content/dam/kpmg/pdf/2015/03/FICCI-KPMG_2015.pdf.

8 https://www.moviemaker.com/archives/moviemaking/directing/articles-directing/the-fall-of-bolly wood-3235/.
} 
to deter piracy. Consequently, yet again the importance of large film budgets is highlighted as the production of 3D or IMAX films is particularly costly.

Ultimately, the Indian film industry has faced increasing difficulties in recent years: even increased investment in the film industry by large Hollywood companies and the release in India of internationally produced films has not stemmed falls in audience numbers. The industry is competitive with the capacity to benefit local economies across the country, but the key theme to emerge from this analysis is that funding for large budget films is crucial, and in the future, this may include funding for more enhanced format films. Other mature film markets across the world including in the USA and UK are also struggling to attract cinema audiences, and as a result, film markets are increasingly competitive, with competition from internationally as well as domestically produced films. The Indian film industry cannot afford to delay investments. The continued importance of the Indian film industry cannot be overstated. Governments, both state level and national, must consider whether their policies are sufficient to encourage film funding, should question whether entertainment taxes stifle investment and if policies are sufficiently effective in combating film piracy.

Acknowledgements The authors are grateful to participants at the British Northern Universities India Forum workshop at the University of Bradford, March 2016, and the International Symposium on Innovation, Catch-Up and Internationalisation: Comparative Studies of China, India and other Emerging Economies, Southwestern University of Finance and Economics, Chengdu, July 2016, for very valuable comments and suggestions.

Open Access This article is distributed under the terms of the Creative Commons Attribution 4.0 International License (http://creativecommons.org/licenses/by/4.0/), which permits unrestricted use, distribution, and reproduction in any medium, provided you give appropriate credit to the original author(s) and the source, provide a link to the Creative Commons license, and indicate if changes were made.

\section{Appendix 1: Variable information}

\begin{tabular}{|c|c|c|}
\hline Variable & Definition & Data Source \\
\hline TOTAL REVENUE & Total box office revenues & www.bollywoodhungama \\
\hline OPENING WEEK REVENUE & Opening week box office revenues & www.bollywoodhundgama.com \\
\hline$B U D G E T$ & Film production budget & $\begin{array}{l}\text { www.imdb.com } \\
\text { www.ibtimes.com } \\
\text { http://www.bollymovierevie } \\
\text { wz.com/ } \\
\text { www.koimoi.com } \\
\text { https://www.cinemalytics.com/ }\end{array}$ \\
\hline STARPOWER & $\begin{array}{l}\text { Dummy variable equal to unity, if } \\
\text { lead actor/actress has been in the } \\
\text { top five TIMES Celebex ranking } \\
2012-2015\end{array}$ & www.timescelebex.com \\
\hline DIRECTORPOWER & $\begin{array}{l}\text { Count variable of the number of } \\
\text { films previously directed by a } \\
\text { director }\end{array}$ & www.imdb.com \\
\hline
\end{tabular}




\begin{tabular}{|c|c|c|}
\hline Variable & Definition & Data Source \\
\hline $\begin{array}{l}\text { DISTRIBUTOR } \\
\text { DISTRIBUTORFAM } \\
\text { DISTRIBUTORFAM10 }\end{array}$ & $\begin{array}{l}\text { Dummy variable equals to unity } \\
\text { if a film is distributed by one of } \\
\text { the ten largest Indian distribu- } \\
\text { tors } \\
\text { Dummy variable equals to unity if } \\
\text { a film is distributed by a family } \\
\text { owned firm } \\
\text { Dummy variable equals to unity if } \\
\text { a film is distributed by a top ten, } \\
\text { family owned distribution firm }\end{array}$ & $\begin{array}{l}\text { www.forbesindia.com } \\
\text { www.ceoworld.biz } \\
\text { www.indiaeinfo.com }\end{array}$ \\
\hline SEASON & $\begin{array}{l}\text { Dummy variable equals to unity } \\
\text { if a film is released during a } \\
\text { national or religious holiday/ } \\
\text { festival season }\end{array}$ & \\
\hline CRICKET & $\begin{array}{l}\text { Dummy variable equals to unity } \\
\text { if a film is released during the } \\
\text { IPL season }\end{array}$ & \\
\hline GENRE & $\begin{array}{l}\text { Set of dummy variables taking the } \\
\text { value unity, if a film is a com- } \\
\text { edy; romance; action/thriller; } \\
\text { drama }\end{array}$ & \\
\hline SEQUEL & $\begin{array}{l}\text { Dummy variable equals to unity if } \\
\text { a film is a sequel }\end{array}$ & www.imdb.com \\
\hline CRITIC & $\begin{array}{l}\text { Times of India critical review } \\
\text { score }\end{array}$ & http://timesofindia.indiatimes.com/ \\
\hline ONLINEREVIEW & $\begin{array}{l}\text { Mean online scores of cinemago- } \\
\text { ers submitted to imdb.com }\end{array}$ & www.imdb.com \\
\hline
\end{tabular}

\section{Appendix 2: Star actors and actresses}

Film star

Actors

Amitabh Bachchan

201320142015

Ajay Devgan

2014

Varun Dhawan

2015

Ranbir Kapoor

2013

Aamir Khan

201220132014

Saif Ali Khan

2012

Salman Khan

2012201320142015

Shah Rukh Khan

2012201320142015

Akshay Kumar

2012

Ranveer Singh

2015

Actresses

Priyanka Chopra

201320142015 


\begin{tabular}{ll}
\hline Film star & Year in Top five \\
& CELEBEX ranking \\
\hline Yami Gautam & 2015 \\
Katrina Kaif & 2013 \\
Kajol & 2015 \\
Kareena Kapoor & 2015 \\
Sonam Kapoor & 2014 \\
Deepika Padukone & 201320142015 \\
Anushka Sharma & 2014 \\
Sonakshi Sinha & 20132014 \\
\hline
\end{tabular}

Full year data on actresses in the ranking were not provided until 2013

\title{
Appendix 3: List of festivals and holidays
}

\author{
26 January: Republic Day \\ Holi (Festival of Colours) \\ Eid al-Fitr, Ramadan, Jamat Ul-Vida and Muharram \\ 15 August: Independence Day \\ 2 October: Gandhi Jayanti \\ Diwali \\ Ganesh Chaturthi \\ Navaratri, Dussehra and Durga Puja \\ Onam \\ 25 December: Christmas \\ 1 January: New Year
}

Where not specified the date of festivals varies from year to year

\section{Appendix 4: OLS regression results}

\begin{tabular}{lll}
\hline Explanatory variable & Dependent variable & \\
\cline { 2 - 3 } & Total revenue & Opening week revenue \\
\hline LOGBUDGET & $0.7228^{* * *}$ & $0.7103^{* * *}$ \\
STARPOWER & $(0.0669)$ & $(0.0676)$ \\
DIRECTORPOWER & 0.0017 & 0.0022 \\
CRITIC & $(0.0021)$ & $(0.0021)$ \\
& 0.0101 & 0.0105 \\
& $(0.0005)$ & $(0.0004)$ \\
& 0.8797 & 0.7497 \\
& $(0.1511)$ & $(0.1643)$ \\
\hline
\end{tabular}




\begin{tabular}{lll}
\hline Explanatory variable & Dependent variable & \\
\cline { 2 - 3 } & Total revenue & Opening week revenue \\
\hline DISTRIBUTORFAMIO & $0.5713^{* * * *}$ & $0.5715^{* * * *}$ \\
SEASON & $(0.1284)$ & $(0.1206)$ \\
& -0.1777 & -0.2114 \\
CRICKET & $(0.2516)$ & $(0.2423)$ \\
ROMANCE & -0.0859 & -0.1048 \\
& $(0.1756)$ & $(0.1671)$ \\
ACTION & -0.0623 & -0.1113 \\
& $(0.1864)$ & $(0.1782)$ \\
DRAMA & -0.2235 & -0.1631 \\
& $(0.1559)$ & $(0.1515)$ \\
SEQUEL & $-0.5892^{* * *}$ & $-0.5781^{* * *}$ \\
CONSTANT & $(0.2099)$ & $(0.2098)$ \\
Observations & $0.6566^{* * *}$ & $0.6315^{* * *}$ \\
$\mathrm{R}^{2}$ & $(0.1915)$ & $(0.1841)$ \\
\hline
\end{tabular}

Multicollinearity is confirmed not to be an issue as we obtained mean VIF scores of 1.3 and 1.32 with total revenue and opening week revenue, respectively, as dependent variables (both VIF scores considerably lower than 10)

Robust standard errors in brackets; *p<0.10; ** $p<0.05 ; * * * p<0.01$

\section{References}

Akdeniz, M. B., \& Talay, M. B. (2013). Cultural variations in the use of marketing signals: A multilevel analysis of the motion picture industry. Journal of the Academy of Marketing Science, 41(5), 601-624.

Bagella, M., \& Becchetti, L. (1999). The determinants of motion picture box office performance: Evidence from movies produced in Italy. Journal of Cultural Economics, 23, 237-256.

Balasubramanyam, V. (2009). The contribution of India's movie industry to the economy; all show and no substance? conference paper presented at the British Northern Universities India Forum 3rd Annual Conference. India: Hyderabad.

Barrett, C. (2016). Big Bash League jumps into top 10 of most attended sports leagues in the world. The Sydney Morning Herald, 11th January, 2016. Accessed at: http://www.smh.com.au/sport/ cricket/big-bash-league-jumps-into-top-10-of-most-attended-sports-leagues-in-the-world-20160 110 -gm2w8z.

Basuroy, S., Chatterjee, S., \& Ravid, S. A. (2003). How critical are critical reviews? The box office effects of film critics, star power and budgets. Journal of Marketing, 67, 103-117.

Brewer, S. M., Kelley, J. M., \& Jozefowicz, J. J. (2009). A blueprint for success in the US film industry. Applied Economics, 41(5), 589-606.

Chang, B.-H., \& Ki, E.-J. (2005). Devising a practical model for predicting theatrical movie success: Focusing on the experience good property. Journal of Media Economics, 18(4), 247-269.

Collins, A., Hand, C., \& Snell, M. (2002). What Makes a Blockbuster? Economic Analysis of Film Success in the UK. Managerial and Decision Economics, 23, 343-354. 
De Vany, A., \& Lee, C. (2001). Quality Signals in Information Cascades and the Dynamics of the Distribution of Motion Picture Box Office Revenues. Journal of Economic Dynamics and Control, 25, 593-614.

De Vany, A., \& Walls, W. D. (1996). Bose-Einstein Dynamics and Adoptive Contracting in the Motion Picture Industry. Economic Journal, 106, 1493-1514.

De Vany, A., \& Walls, W. D. (1999). Uncertainty in the movies: Can star power reduce the terror of the box office? Journal of Cultural Economics, 23, 285-318.

De Vany, A., \& Walls, W. D. (2002). Does Hollywood Make Too Many R-Rated Movies? Risk, Stochastic Dominance and the Illusion of Expectations. Journal of Business, 75, 425-451.

Einav, L. (2007). Seasonality in the U.S. motion picture industry. Rand Journal of Economics, 38(1), $127-145$.

Elberse, A. (2007). The power of stars: Do star actors drive the success of movies? Journal of Marketing, 71, 102-120.

Eliashberg, J., Elberse, A., \& Leenders, M. (2006). The motion picture industry: Critical issues in practice, current research, and new research directions. Marketing Science, 25(6), 638-661.

Eliashberg, J., \& Shugan, S. (1997). Film critics: Influencers or predictors? Journal of Marketing, $61(2), 68-78$.

Elliott, C., Konara, P., Ling, H., Wang, C., \& Wei, Y. (2018). Behind film performance in China's changing institutional context: The impact of signals. Asia Pacific Journal of Management, 35(1), 63-95.

Elliott, C., \& Simmons, R. (2008). Determinants of box office success: The impact of quality signals. Review of Industrial Organization, 33, 93-111.

Fetscherin, M. (2010). The main determinants of Bollywood movie box office sales. Journal of Global Marketing, 23(5), 461-476.

Fu, W. W., \& Lee, T. K. (2008). Economic and cultural influences on the theatrical consumption of foreign films in Singapore. Journal of Media Economics, 21(1), 1-27.

Guptal, P. (2015). Salman Khan tops the Times Celebex ranking for the year 2014. The Times of India, 5th April, 2015. Accessed at: http://timesofindia.indiatimes.com/entertainment/hindi/bolly wood/news/Salman-Khan-tops-the-Times-Celebex-ranking-for-the-year-2014/articleshow/46804 927.cms.

Izquierdo Sanchez, S., Elliott, C., \& Simmons, R. (2016). Substitution between leisure activities: A quasi-natural experiment using sports viewing and cinema attendance. Applied Economics, 48(40), 3848-3860.

Jones, G., Arora, N., Mishra, S., \& Lefort, A. (2008). Can Bollywood go global? Harvard Business School discussion paper, 9-806-040.

Lee, F. F. (2006). Cultural discount and cross-culture predictability: Examining the box office performance of American movies in Hong Kong. Journal of Media Economics, 19(4), 259-278.

Lee, F. F. (2009). Cultural discount of cinematic achievement: The academy awards and U.S. movies' East Asian box office. Journal of Cultural Economics, 33(4), 239-263.

Litman, B. (1983). Predicting success of theatrical movies: An empirical study. Journal of Popular Culture, 16, 159-175.

McCarthy, N. (2014). Bollywood: India's film industry by the numbers. Forbes, September 3rd.

McKenzie, J. (2012). The economics of movies: A literature survey. Journal of Economic Surveys, 26(1), 42-70.

Moon, S., Bayus, B. L., Yi, Y., \& Kim, J. (2015). Local consumers' reception of imported and domestic movies in the Korean movie market. Journal of Cultural Economics, 39(1), 99-121.

Moon, S., Bergey, P. K., \& Iacobucci, D. (2010). Dynamic effects among movie ratings, movie revenues, and viewer satisfaction. Journal of Marketing, 74(1), 108-121.

Prag, J., \& Casavant, J. (1994). An empirical study of the determinants of revenues and marketing expenditures in the motion picture industry. Journal of Cultural Economics, 18, 217-235.

Ravid, S. A. (1999). Information, blockbusters, and stars: A study of the film industry. Journal of Business, 72(4), 463-492.

Ravid, S. A., \& Basuroy, S. (2004). Managerial objectives, the R-rating puzzle, and the production of violent films. Journal of Business, 77(2), S155-S192.

Reinstein, D., \& Snyder, C. (2005). The influence of expert reviews on consumer demand for experience goods: A case study of movie critics. Journal of Industrial Economics, 103(1), 27-51. 
Shoard, C. (2016). China's box office certain to overtake US as takings up 50\% in 2016's first quarter. The Guardian. Accessed at: https://www.theguardian.com/film/2016/apr/01/chinas-box-offic e-certain-to-overtake-us-as-takings-up-50-in-2016s-first-quarter.

Sochay, S. (1994). Predicting the performance of motion pictures. Journal of Media Economics, 53, 27-52.

Walls, W. D. (2005). Modelling heavy tails and skewness in film returns. Applied Financial Economics, 15, 1181-1188.

Publisher's Note Springer Nature remains neutral with regard to jurisdictional claims in published maps and institutional affiliations. 